\title{
IMPACT OF SOLAR RADIATION CHANGE ON THE COLLECTOR EFFICIENTLY
}

\author{
Danuta Proszak-Miąsik' ${ }^{1}$ Sławomir Rabczak ${ }^{1}$ \\ 1 Faculty of Civil, Environmental Engineering and Architecture, Rzeszow University of Technology, Poznańska \\ 2 St., 35-084 Rzeszów, Poland, e-mail: dproszak@prz.edu.pl, rabczak@prz.edu.pl
}

Received: 2016.10.15

Accepted: 2016.11.16

Published: 2017.01.01

\begin{abstract}
In October 2014 in a building of Rzeszow University of Technology, a series of measurements was taken to calculate the parameters of a solar system with a flat collector, as installed on the roof of the building. The following parameters were obtained: the value of solar radiation intensity, the temperature of external air, the temperature on the collector, the temperature of water in the tank and the temperature of glycol on the supply and return lines. On the basis of the data received, charts were made to visually present how changes of solar radiation intensity affected parameters of the system. The study was conducted in autumn when the intensity of solar radiation decreases, compared with summer months. The publication aims to show that the solar system brings energy gains in periods of transition, and the instantaneous intensity of solar radiation are comparable to those in the summer.
\end{abstract}

Keywords: solar radiation, collector, weather conditions.

\section{INTRODUCTION}

Growing ecological consciousness of society concerning the side effects of conventional energy sources exploitation and their higher prices make us use renewable sources of energy more frequently. Renewable sources of energy are available almost in unlimited amounts and a useful form of energy can be created from them by applying a specially designed technological system. One of the most effective way of acquiring solar energy in climatic conditions prevailing in Poland is using solar collectors with tanks for heating tap water [Dąbrowski, 2009].

The main problem with receiving solar energy using collectors is a varied inflow of energy in different times of the day and seasons of the year, as well as low radiant flux density [Dąbrowski, 2009]. By the notion of solar radiation, we understand the transfer or emission of energy in a form of electromagnetic waves. Radiation emitted from the surface of the Sun is spread in all directions in the space and reaches the surface of the Earth.

The most essential parameters of solar radiation are: daily, monthly and annual sums of solar radiation density. They express an amount of solar energy which falls on a surface unit at a given time.

The total solar radiation value consists of:

- direct radiation, i.e. short-lived radiation in which rays are spread in a straight line from the Sun to the active surface of the collector. Therefore, the wider is the angle of sunrays falling on the collector, the larger amount of energy is absorbed.

- diffuse radiation, also known as scattered radiation, is longwave radiation. It is created by reflecting, refracting or partly by absorbing direct radiation in the Earth's atmosphere. Power gains from diffuse radiation are, in fact, smaller than from direct radiation. Some collectors are not able to transform diffuse radiation into heat.

- reflected radiation is created as a result of reflecting rays from the surface of the Earth and objected situated near the absorber. Sometimes such rays reach the active surface of solar collectors without any obstacles. 
The purpose of a solar collector is to absorb sunrays, to transforming them into heat and, finally, to give it up to the flowing heat carrier. A collector is one of the most important elements of the solar system [Albers, 2007; Kalogirou, 2014].

The solar system consists of a solar glass pane, an absorber, a collector housing and tubes which supply and carry away the heating medium.

\section{INFLUENCE OF METEOROLOGICAL CONDITIONS ON WORK OF SOLAR SYSTEM}

How much energy is obtained by the solar collector is to a large extent affected by weather conditions, such as time of year, seasonal changes in the angle of incidence of solar irradiance, length of day, cloud cover, humidity and the presence of airborne water vapor and aerosols that affect transparency and absorption properties of air. To summarize, the main meteorological factors that have an influence on obtaining energy from the sun by collectors are: sunshine duration, radiation and total ambient air temperature [Dabrowski and Hutnik, 2015].

According to the meteorological Dictionary (2003), solar irradiance is the number of hours during which the sun is not obscured by clouds, or the time of occurrence of direct radiation; for the measurement of sunshine duration is heliograph. Poland, the annual sunshine duration is between 1390-1900 hours (depending on region), and the contents of the average takes 1600 hours.

While the annual sum of the total radiation that reaches the land surface at a certain point, indicates the amount of solar energy which can be used in this place throughout the year, and this is in accordance with the Polish PN-EN ISO 9488 [Chwieduk 2004] irradiance or the power density of incident radiation on the surface, ie. the ratio of the radiant flux incident on a surface and the field surface or the amount of energy per unit time that passes through the unit area of the surface $\left(\mathrm{W} \cdot \mathrm{m}^{-2}\right)$. In Poland, it is about $950 \mathrm{kWh} / \mathrm{m}^{2}$.

Hence, the overall intensity of solar radiation that falls on the plane tangent to the Earth's surface is given by:

$$
I_{G}=I_{h}+I_{R}
$$

where: $I_{h}$ means the intensity of the direct radiation reaching the Earth, and the $I_{R}$ intensity of the scattered radiation. Increase in the intensity of solar radiation implies the increase of temperature, which significantly affects the control parameters.

Summing up, the energy that reaches the solar collector in June under a clear sky is the highest and accounts for about $90 \%$ of total radiation that reaches the Earth, the Sun is then high above the horizon $\left(62.4^{\circ}\right)$, and the radiation intensity is up to $1050 \mathrm{~W} \cdot \mathrm{m}^{-2}$. When the sky is completely overcast sky, the intensity of the scattered radiation in the same period is $50-150 \mathrm{~W} \cdot \mathrm{m}^{-2}$. The smallest number of solar irradiance hours in the winter, is due to the position of the sun relative to the horizon, the lower ambient temperatures and stronger winds occurring at this time. In December, the sun is lowest over the horizon $\left(15.5^{\circ}\right)$ hence the intensity of radiation amounts to $10-100 \mathrm{~W} \cdot \mathrm{m}^{-2}$.

While estimating the energy yield from the system, the most useful value is the solar irradiance. It is the sum of solar radiation at a given time for a given area (e.g. total solar radiation during the hours of the day or year on the surface of $1 \mathrm{~m}^{2}$ ). Solar irradiance is a value describing the amount of solar energy per surface area in a given period of time. Solar irradiance is most often expressed in $\mathrm{kWh} / \mathrm{m}^{2}$ per year. For Poland it is in the range of $1050-1150 \mathrm{kWh} / \mathrm{m}^{2} /$ year [Matuszczyk and Poplawski, 2015]. The better the atmospheric conditions, the higher the values of solar radiation intensity and more beneficial values of solar system parameters [Quaschning 2004].

\section{METHODOLOGY AND SCOPE OF RESEARCH}

On 15 October 2014 at the Rzeszów University of Technology, a series of measurements was taken to calculate parameters of a solar system with a flat collector (Fig. 1). The solar collector is installed on the roof of building over the room, it is pointed to the south-west and situated at an angle of $45^{\circ}$ to the surface of the Earth. Measurements of total solar radiation was performed using solarimeter Pyra LP 02. Pyranometer measures the radiance on a plane surface $\left(\mathrm{W} / \mathrm{m}^{2}\right)$. Measured irradiance is the result of the sum of direct solar irradiance and of diffuse irradiance. LP PYRA 02 is a First Class pyranometer in Accordance with ISO 9060 standard Pyranometers. LP PYRA 02 are well suited for the measurement of incoming global solar radiation $(0.3 \mu \mathrm{m} \div 3 \mathrm{mi}-$ crometer spectral range). 


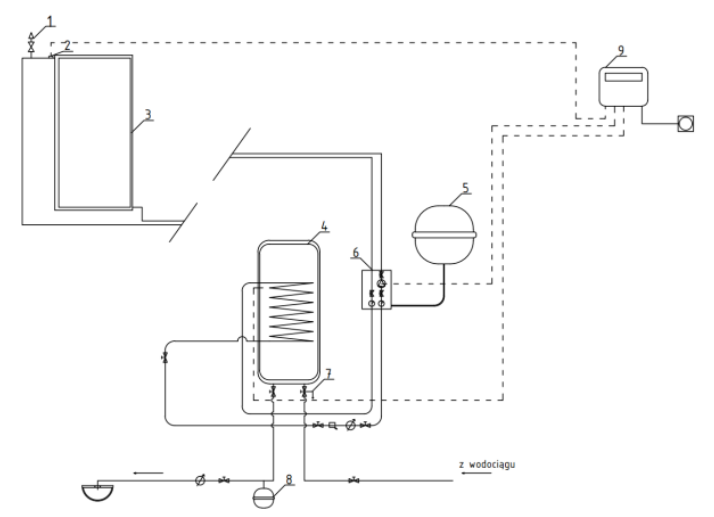

Figure 1. Schema of the solar system: $1-$ vent; $2-$ temperature sensor; 3 - solar collector panel; 4 - solar water tank 1001; 5 - expansion vessel 351 ; 6 - working station; 7 - drain valve; 8 - expansion vessel 81 , 9 - display

Initially, favourable atmospheric conditions prevailed on that day, as it was sunny and cloudless; however, as the time passed, more and more clouds gathered causing a fall of solar radiation intensity, which oscillated from approx. $400 \mathrm{~W} /$ $\mathrm{m}^{2}$ (at the beginning of the measurements) to approx. $150 \mathrm{~W} / \mathrm{m}^{2}$ (at the end).

During taking the measurements, the following values were obtained:

- the value of solar radiation intensity,

- the temperature of external air,

- the temperature on the surface of the collector,

- the temperature of water in the tank,

- the temperature of glycol on the supply and return lines.

The system installed is a standard solar system with a flat collector which aims to heat tap water for laboratory purposes.

During the research made from $9^{05}$ to $14^{05}$, changeable weather conditions prevailed. Initially, it was sunny. However, with time, light clouds appeared, which was noticeable in the recorded results of solar radiation intensity. Such values fluctuated from $350-400 \mathrm{~W} / \mathrm{m}^{2}$ at the beginning of taking the measurements up to 150-200 W/ $\mathrm{m}^{2}$ at the end. On the basis of the measurements results included on particular charts, it was analysed to what extent the solar radiation intensity affects the efficiency of the solar system.

\section{RESULTS AND DISCUSSION}

Using eight charts, the following relationships were presented:
- how changes of radiation intensity affect the temperature of water in the tank (Fig. 2),

- how changes of radiation intensity affect the temperature on the collector (Fig. 3),

- how changes of radiation intensity affect the temperature of glycol on the supply line (Fig. 4),

- how changes of radiation intensity affect the temperature of glycol on the return line (Fig. 5),

- relationship between the changes of radiation intensity and the changes of air temperature (Fig. 6),

- relationship between the changes of temperature on the collector and the changes of temperature of water in the tank (Fig. 7),

- relationship between the changes of temperature of water in the tank and the changes of temperature of glycol on the supply and return lines (Fig. 8).

\section{CONCLUSIONS}

Changes of radiation intensity are reflected in changes of the temperature of water in the tank (Fig. 2), on the collector and the temperature of glycol on the supply and return lines. We may notice that at the beginning, when more favourable atmospheric conditions prevailed, higher values of radiation intensity were observed. The value of temperature in the tank increased faster than at the end of charging process, when clouds appeared. Temperatures in the collector (Fig. 3) and of glycol (Fig. 4 and Fig. 5) fluctuated as the intensity was changing. From the chart (Fig. 7) it may also be concluded that when the temperature on the collector was increasing, a faster rise of temperature of water in the tank was observed, whereas when it was decreasing, lower

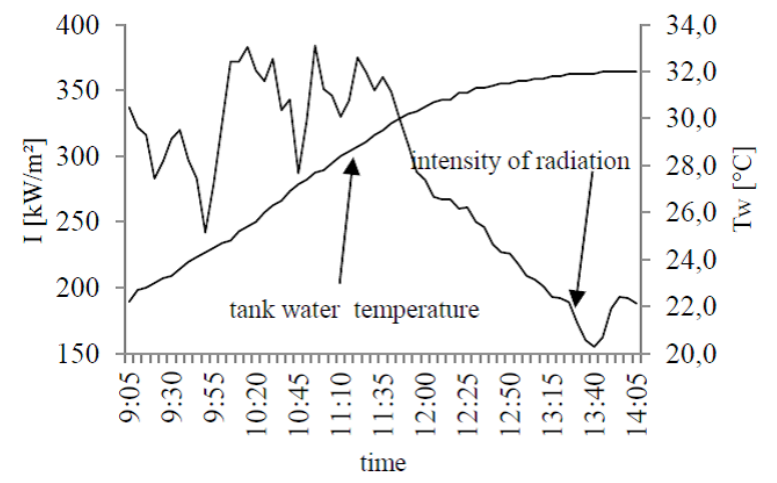

Figure 2. Impact of changes in the intensity of radiation (I) on the temperature of the water in the tank (Tw). 


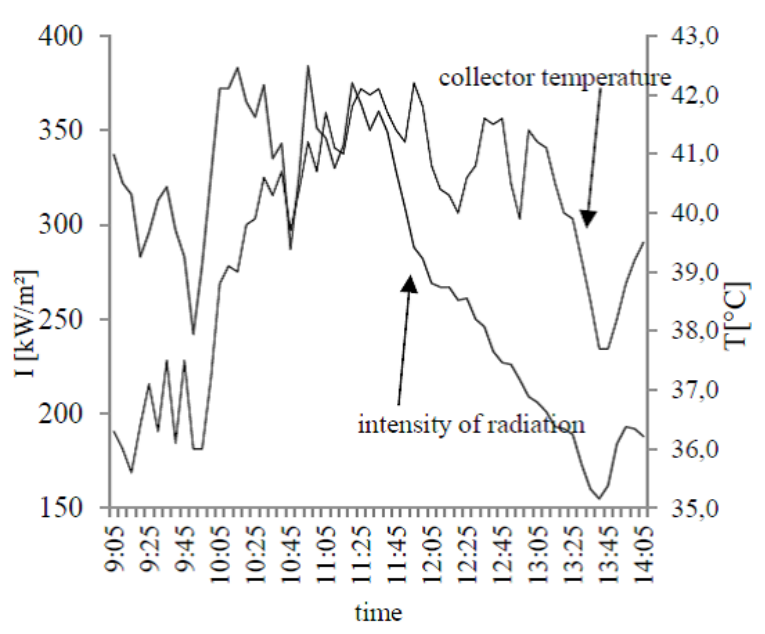

Figure 3. Effect of changes in the intensity of radiation (I) on the temperature of the collector (T).

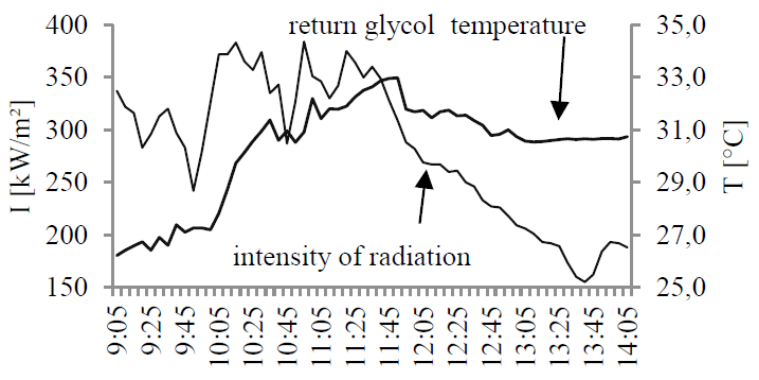

time

Figure 5. Impact of changes in the intensity of radiation (I) on the temperature glycol return (Tg).

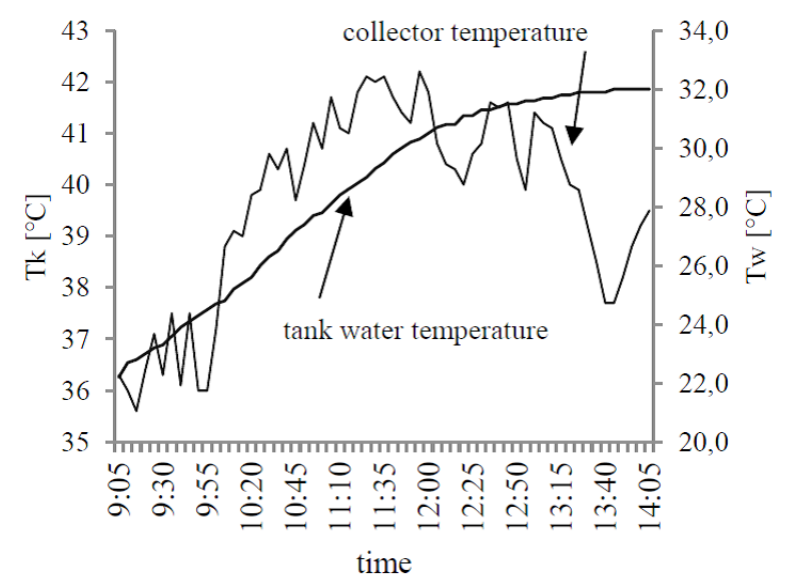

Figure 7. Temperature changes on the collector with a change of water temperature in the tank.

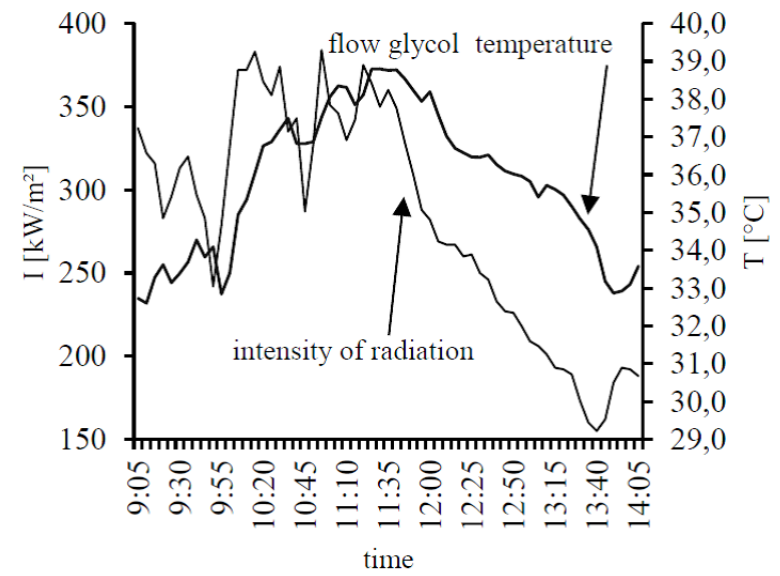

Figure 4. Impact of changes in the intensity of radiation (I) on the temperature glycol flow (Tg).

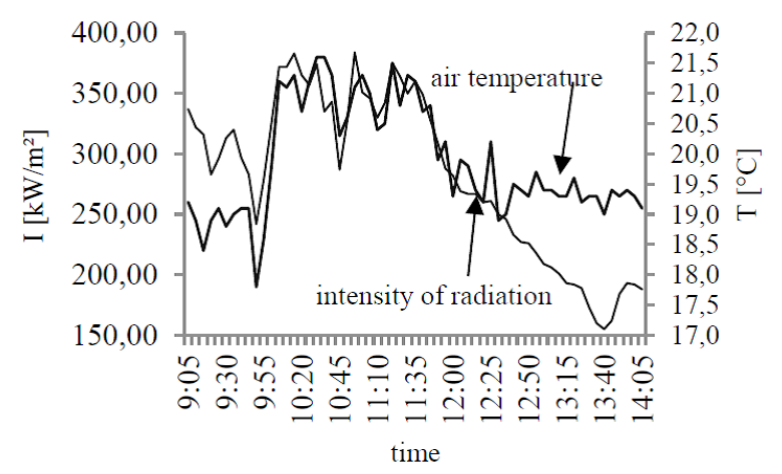

Figure 6. The dependence of the radiation intensity changes (I) with the change in air temperature (T)

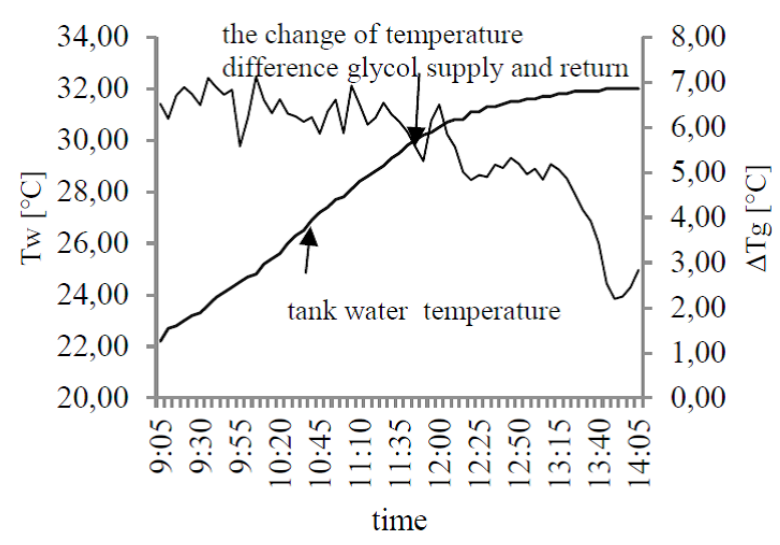

Figure 8. Changes in water temperature in the tank with the change of temperature difference glycol supply and return. 
and lower increase in temperature of warm tap water was noted. Also, the relationship between the temperature of water in the tank and the changes of temperature of glycol on the supply and return lines may be described in a similar manner (Fig. 8).

Changes of radiation intensity have a significant influence on the efficiency of the collector installed in the system in question. The fluctuations of intensity and atmospheric conditions during different times of the day and seasons of the year are an essential problem with receiving solar energy using collectors.

The most favourable conditions for the operation of a solar system are at noon when the Sun is at its zenith and when the sky is cloudless and sunrays reach the collector without any obstacles.

\section{REFERENCES}

1. Albers J., Dommel R. and Montaldo-Ventsam H. 2007. Systemy centralnego ogrzewania i wentylacji, Poradnik dla projektantów i instalatorów. Warszawa.
2. Chwieduk D. 2006. Modelowanie i analiza pozyskiwania oraz konwersji termicznej energii promieniowania słonecznego w budynku. Instytut Podstawowych Problemów Techniki PAN. Warszawa.

3. Dąbrowski J. 2009. Kolektory słoneczne do podgrzewania ciepłej wody użytkowej. Efektywność i opłacalność instalacji. Wrocław.

4. Dąbrowski J. and Hutnik E. 2015. Badania wykorzystania energii słonecznej w budynku mieszkalnym wyposażonym w kolektory słoneczne. Instal, 6, 26.

5. Kalogirou, S. 2014. Solar Energy Engineering (Second Edition), 22-33, 257-321.

6. Matuszczyk P., Popławski T. and Flasza J. 2015. Przegląd Elektrotechniczny, 91(12).

7. Proszak-Miąsik D., Nowak K. and Rabczak S. 2013. Wykorzystanie energii słonecznej, jako jednego z czynników poprawiających jakość powietrza. Journal of Civil Engineering, Environment and Architecture, 60(3), 239.

8. Niedźwiedź T. 2003. Słownik meteorologiczny. PTGeofiz., IMGW, Warszawa.

9. Quaschning V. 2004. Solar thermal water heating, Renewable Energy World 02/2004, 95-99. 